\title{
Genetic diversity of Matrinxã breeding stocks: implications for management and conservation
}

\section{Diversidade genética em estoques de reprodutores de Matrinxã: implicações para o manejo e conservação}

Angela Maria Urrea-Rojas ${ }^{1}$; Felipe Pinheiro de Souza1; Ed Christian Suzuki de Lima'; Claudete de Fátima Ruas²; Ligia Uribe Gonçalves³; Jayme Aparecido Povh4; Denise Rocha Ayres ${ }^{5}$; Annaiza Braga Bignardi5; Ulisses de Pádua Pereira6, Nelson Mauricio Lopera-Barrero ${ }^{7 *}$

\section{Highlights}

Amplification of heterologous microsatellite primers in B. amazonicus.

Moderate diversity was found in the breeding stocks of matrinxã.

The breeding stocks presented a common genetic origin.

\begin{abstract}
The formation of fish breeding stocks for fish farming or conservation programs is commonly carried out from the capture of fish in natural environments. Information on the geographic and genetic origin of these stocks is important to guide actions that allow correct management in captivity and, when lost, harm production and genetic conservation. In this sense, the objective of this study was to evaluate the genetic diversity and origin of two breeding stocks of matrinxã, Brycon amazonicus (INPA, Amazonas - INPA and Nova Motum, Mato Grosso - NM). A total of 68 caudal fin samples were collected, including 33 INPA samples and 35 NM samples. Twenty pairs of microsatellite primers were tested, but only seven primers showed satisfactory amplification, amplifying 41 alleles ranging from $187-318 \mathrm{bp}$. The polymorphic information content ranged from 0.135 (Borg25) to 0.782 (Bh6). Exclusive alleles were observed for both populations (INPA: 04 and NM: 18). Allelic richness results revealed that there was increased loss of genetic variation in NM, indicating a

1 Ph.D. Students, Department of Animal Science, State University of Londrina, UEL, Londrina, PR, Brazil. E-mail: amur03013@gmail.com; felipeps1991@gmail.com; edchris7@hotmail.com

2 Professor, Department of Biology, Center for Biology Science, UEL, Londrina, PR, Brazil. E-mail: ruas@uel.br

${ }^{3}$ Researcher of the National Amazon Research Institute, INPA, Manaus, AM, Brazil. E-mail: ligia.inpa@gmail.com

${ }^{4}$ Professor of the Faculty of Veterinary Medicine and Animal Science, Federal University of Mato Grosso do Sul, UFMS, Campo Grande, MS, Brazil. E-mail: jayme.povh@ufms.br

${ }^{5}$ Professor of the Institute of Agricultural and Technological Sciences, Federal University of Rondonópolis, UFR, Rondonópolis, MT, Brazil. E-mail: derocay@gmail.com; annaizabb@gmail.com

${ }^{6}$ Professor of the Department of Preventive Veterinary Medicine and Postgraduate Department of Animal Science, UEL, Londrina, PR, Brazil. E-mail: upaduapereira@uel.br

7 Professor of the Department of Animal Sciences and Postgraduate Program in Animal Science, UEL, Londrina, PR, Brazil. E-mail: nmlopera@uel.br

* Author for correspondence
\end{abstract}

Received: Mar 06, 2020 - Approved: Nov. 30, 2020 
lower evolutionary potential of this stock. The average values of the observed heterozygosity corroborated this statement; however, there were high values for INPA (0.545) and NM (0.475), signifying an adequate genetic variability. An imbalance was found in the Hardy-Weinberg equilibrium at the Borg59 locus in INPA ( $P$ $<0.05$ ), possibly due to the effect of null alleles, but was attributed to a founder effect. For NM, an imbalance in the Hardy-Weinberg equilibrium was observed at loci BoM13 and Bh6, which together with the results of the mean inbreeding coefficient values demonstrated the presence of genetic drift. The analysis of molecular variance showed greater variation within populations than between them, and was confirmed by the genetic differentiation value (0.086 - moderate genetic differentiation) and by the distance and genetic identity values ( 0.273 and 0.761 , respectively). Bayesian analysis designated a value of $K=2$, with the presence of structuring for NM and INPA; however, with correlated allelic frequencies, confirming a common origin. This origin was corroborated by the presence of gene flow through the number of migrants (5.691). Based on these results, there was a moderate genetic variability for INPA and NM and their common origin was confirmed. Recommendations are also included to minimize the probability of inbreeding processes or genetic drift in the studied stocks..

Key words: Brycon amazonicus. Conservation. Genetic diversity. Microsatellite.

\section{Resumo}

A formação de estoques de reprodutores de peixes objetivando a piscicultura ou programas de conservação é comumente realizada a partir da captura de peixes em ambientes naturais. As informações da origem geográfica e genética desses estoques são importantes para orientar ações que permitam o correto manejo no cativeiro e, quando perdidas, podem prejudicar a produção e a conservação genética. Nesse sentido, o objetivo deste estudo foi avaliar a diversidade genética e origem de dois estoques de reprodutores de Matrinxã - Brycon amazonicus (INPA, Amazonas - INPA; Nova Motum, Mato Grosso - NM, respectivamente). Foram coletadas 68 amostras de nadadeira caudal (INPA: 33 amostras e NM: 35 amostras). Um total de 20 pares de primers microssatélites foram testados dos quais somente sete primers mostraram amplificação satisfatória, permitindo a amplificação de 41 alelos variando entre 187 e 318 pb. O conteúdo de informação polimórfica variou de 0,135 (Borg25) a 0,782 (Bh6). Foram observados alelos exclusivos para as duas populações (INPA: 04 e NM: 18). Os resultados de Riqueza alélica verificaram que houve maior perda de variação genética em NM, demonstrando a existência de um menor potencial evolutivo nesse estoque. Os dados médios da heterozigosidade observada corroboraram essa afirmação, porém, com valores altos para INPA $(0,545)$ e NM $(0,475)$, demonstrando uma variabilidade genética adequada. Foi observado o desvio no equilíbrio de Hardy-Weinberg $(P<0,05)$ no loco Borg59 em INPA possivelmente pela presença efeito de alelos nulos, mas principalmente atribuído à presença do efeito fundador. Para NM foram observados desvios no equilíbrio de Hardy-Weinberg em BoM13 e Bh6, que junto aos resultados dos valores médios de FIS evidenciaram a presença de deriva genética. A análise da variância molecular mostrou maior variação dentro das populações do que entre elas, sendo confirmado pelo valor de diferenciação genética (0,086 - moderada diferenciação genética) e pelos valores da distância e identidade genética (0,273 e 0,761, respectivamente). A análise Bayesiana designou um valor de $\mathrm{K}=2$, com presença de estruturação para NM e INPA, porém, com frequências alélicas correlacionadas, confirmando uma origem comum. Esta origem foi corroborada pela presença de fluxo gênico através do número de migrantes $(5,691)$. Com base nos resultados, confirma-se a existência de moderada variabilidade genética para INPA e NM e sua origem 
comum. Conclui-se o artigo com algumas recomendações para minimizar a probabilidade de processos endogâmicos ou de deriva genética nos estoques estudados..

Palavras-chave: Brycon amazonicus. Conservação. Diversidade Genética. Microssatélites.

\section{Introduction}

Matrinxã, Brycon amazonicus (Spix \& Agassiz, 1829), is a migratory fish from the Amazon River basin, found throughout the Solimões-Amazonas river system and its tributaries (Lima, 2003; Santos \& Batista, 2009; Silva et al., 2017). Due to its fast growth and good zootechnical parameters, it has a high commercial value in fish farming (Abreu \& Urbinati, 2006), and is the second most farmed species in the Amazon region (Oliveira et al., 2018). In 2016, matrinxã production was $8.766,980 \mathrm{Kg}$ (Instituto Brasileiro de Geografia e Estatística [IBGE], 2016). These characteristics, together with their favorable organoleptic characteristics and adaptability to cultivation systems, have led to matrinxã farming in several Brazilian states (AraujoDairiki, Chaves \& Dairiki, 2018).

In general, the formation of captive breeder stocks results from the removal of individuals from nature (Oliveira et al., 2018). The maintenance of these stocks is based mainly on the occasional introduction of new individuals (from natural populations or other stocks) and reproductive control to reduce inbreeding depression Aguiar et al. (2018). For any of these managements, constant genetic monitoring is important, both in captive stocks and in the natural populations from which they are obtained (Oliveira et al., 2018). Thus, the lack of knowledge about fish origin limits the necessary management to maintain genetic variability and, in parallel, impairs productive parameters in fish farms.
Therefore, the objective of this study was to evaluate the genetic diversity of a stock and a natural population of matrinxã, Brycon amazonicus, and to verify the probable origin of the stock from this natural population.

\section{Materials and Methods}

The study was approved by the Ethics Committee of the State University of Londrina, (CEUA_UEL $\left.n^{\circ} 11679.2017 .46\right) . \quad$ Caudal fin samples (approximately $0.5 \mathrm{~cm}^{2}$ ) were randomly collected in two different locations: 33 samples of breeders kept in captivity by the National Research Institute of the Amazon (INPA), those specimens were collected in the wild at llha da Marchantaria, at the meeting of the waters of the Negro and Solimões rivers in the state of Amazonas, Brazil ( $3^{\circ} 14^{\prime} 57.5$ "S $\left.59^{\circ} 58^{\prime} 18.4^{\prime \prime} \mathrm{O}\right)$, and 35 samples from a fish farm in Nova Mutum (NM), Mato Grosso, Brazil (134 44'57.1" S $\left.56^{\circ} 05^{\prime} 10.5^{\prime \prime O}\right)$. The breeding stocks were used to produce fingerlings for fish farms through hormonal induction and extrusion.

DNA extraction was performed using the methodology described by Lopera-Barrero etal. (2008). DNA was quantified using the SLIPQ 026 Quantifier L-Quant spectrophotometer (Loccus Biotecnologia, Ribeirão Preto, Brazil) and the samples were diluted to $30 \mathrm{ng} / \mathrm{\mu L}$. DNA integrity was verified by electrophoresis on a $1 \%$ agarose gel stained with SYBR Safe TM DNA Gel Stain (Invitrogen, Carlsbad CA, USA), and run at 100 volts for $60 \mathrm{~min}$. Electrophoresis 
was performed in 0.5× TBE buffer $(250 \mathrm{mM}$ Tris- $\mathrm{HCl}, 30 \mathrm{mM}$ boric acid, and $41.5 \mathrm{mM}$ EDTA). DNA was visualized on a transilluminator using ultraviolet light and was photographed with a Kodak EDAS camera (1D Image Analysis 3.5 Kodak, Horsham PA, USA). Analyzes were performed at the Aquaculture and Genetics Research Center (NEPAG) of Universidade Estadual de Londrina (UEL).

Twenty microsatellite primer pairs were tested: 04 were species-specific for Brycon amazonicus, including Bag22, Bag25, Bag27, and Bam11 Araujo (2012), while 16 were heterologous. These included BoM13 and BoM6 from Brycon opalinus (Barroso et al., 2003), Bh5 and Bh6 from Brycon hillari (Sanches \& Galetti, 2006), and the following from Brycon orbignyanus: Borg4, Borg9, Borg10, Borg12, Borg13, Borg17, Borg25, Borg54, Borg55, Borg56, Borg59, and Borg69 (Souza et al., 2018a). Polymerase chain reactions were performed at a final volume of $10 \mu \mathrm{L}$ containing $2.78 \mu \mathrm{L}$ ultrapure $\mathrm{H}_{2} \mathrm{O}, 4.5 \mu \mathrm{L}$ GoTaq Green Master (Promega, Madison, WI, USA), $0.08 \mu \mathrm{L}$ forward primer, $0.32 \mu \mathrm{L}$ reverse primer, $0.32 \mu \mathrm{L}$ M13 primer labeled with FAM, HEX, NED or PET probes (Applied Biosystems), and $2 \mu \mathrm{L}$ DNA. DNA was denatured at $94^{\circ} \mathrm{C}$ for 4 min, followed by 35 cycles of 35 s each at 94 ${ }^{\circ} \mathrm{C}$, continuing with $1 \mathrm{~min}$ of annealing and 60 $\mathrm{s}$ of extension at $72^{\circ} \mathrm{C}$; and a final extension for $10 \mathrm{~min}$ at $72^{\circ} \mathrm{C}$ in the Veriti ${ }^{\circledR}$ thermocycler (Applied Biosystems ${ }^{\circledR}$, Austin, TX, USA).

Two microliters of amplified products were mixed with $16 \mu \mathrm{L}$ of ultrapure $\mathrm{H}_{2} \mathrm{O}$. From this mixture, $1 \mu \mathrm{L}$ was added to $8.8 \mu \mathrm{L}$ of $\mathrm{Hi}-\mathrm{Di}$ formamide (Applied Biosystems) and $0.2 \mu \mathrm{L}$ standard size 600-LIZ (GeneScan v2.0) was used as a molecular weight standard. Samples were denatured at $95^{\circ} \mathrm{C}$ for $3 \mathrm{~min}$, immediately placed on ice, and then subjected to capillary electrophoresis in an automated ABI $3500 \mathrm{xL}$ Genetic Analyzer system (Applied Biosystems, CA). Fragment size was determined using the GeneMarker $^{\circledR}$ 2.4.0 program.

The number of alleles, allele frequency, allele richness $(\mathrm{Ra})$, exclusive alleles, and the inbreeding coefficient $\left(F_{I S}\right)$ were calculated using the FSTAT 2.9.3 (Goudet, 2005) program, applying the Bonferroni correction to evaluate significance $(P<0.05)$. The number of migrants $(\mathrm{Nm})$ was calculated using the GenAlex program version 6.5 (Peakall \& Smouse, 2012). The expected $(\mathrm{He})$ and observed $(\mathrm{Ho})$ heterozygosity, the HardyWeinberg equilibrium test (HWE, $\mathrm{P}<0.05)$, the molecular variance analysis (AMOVA), and genetic differentiation (fixation index, FST) were estimated using the Arlequin 3.5 program (Excoffier \& Lischer, 2010). HWE values were corrected by Bonferroni (Rice, 1989). As a method of differentiating FST values, Wright (1978) classification has been implemented, where values between 0.00$0.05,0.05-0.15,0.15-0.25$, and $>0.25$ indicate small, moderate, high, and very high genetic differentiation, respectively. The distance (DG) and genetic identity (IG) were calculated using the program PopGene 1.32 (Yeh, Boyle, \& Xiyan, 1999). The presence of null alleles was determined using the Micro-Checker program (Van Oosterhout, Hutchinson, Wills, \& Shipley, 2004). Polymorphic information content (PIC) for each locus has been calculated using Cervus 3.0.7 (Kalinowski, Taper, \& Marshall, 2007), using the classification proposed by Botstein, White, Skolnick, \& Davis (1980), where PIC values < 0.25, between 0.25-0.5 and > 0.5 indicate low, medium, and high polymorphism. 
STRUCTURE V.2.3.3 (Pritchard, Stephens, \& Donnelly, 2000) was used to verify the existence of possible clusters $(K)$ of genetically similar populations, following the mixed model of clusters with 250,000 Markov and Monte-Carlo (MCMC) chains and a running length of 1,000,000 MCMC. The K estimates (number of clusters) were obtained from simulations performed with $\mathrm{K}$ varying from one to five $(K=1-5)$, reproducing 20 interactions for each tested $K$ value. The number of clusters has been determined using the proposed method by Evanno, Regnaut and Goudet (2005), and implemented on the Structure Harvester website (Earl, 2012).

\section{Results and Discussion}

Of the 20 primer pairs tested, only seven showed amplification and included two species-specific (Bag22 and Bag27) and five heterologous primers (Bom13, Bh5, Bh6, Borg25, and Borg59). The amplified loci generated 41 alleles and the total number of alleles per locus ranged from three (Borg25) to nine (Bom13), with sizes between 187 bp (Bom13) and 318 bp (Bag22) (Table 1). The size of the alleles produced is similar to that observed in previous research carried out on B. opalinus (Barroso et al., 2003), B. amazonicus (Araujo 2012), B. hillari (Sanches \& Galetti, 2006), and B. orbignyanus (LoperaBarrero et al., 2014; Castro et al., 2017; Souza et al., 2018a), demonstrating that the region flanked by the primers has a mostly constant size, despite variations in the annealing site, allowing cross/heterologous amplification.

The largest number of alleles was found using the primers BoM13 (9) and Bh5 (8) and the PIC ranged from 0.135 (Borg25) to 0.782 (Bh6). According to the classification by Botstein et al. (1980), the Bag22, Bag27, BoM13, Bh5, Bh6, and Borg59 loci have high polymorphism and are very informative, while the Borg25 locus has low polymorphism and presents little information. Eighteen exclusive alleles were observed in the INPA natural population and four alleles in the NM breeding stock. The most frequent exclusive allele in INPA and NM was $233 \mathrm{pb}$ and $224 \mathrm{pb}$, both for the Bh5 locus, with $32 \%$ and $72 \%$ frequency, respectively (Table 2 ). 
Table 1

Characterization of microsatellite loci, SSRs motif, Sequence Primer (5'-3'), annealing temperature (TA ${ }^{\circ} \mathrm{C}$ ) and species development

\begin{tabular}{|c|c|c|c|c|c|}
\hline Locus & $\begin{array}{l}\text { GenBank } \\
\text { access }\end{array}$ & SSR motif & Sequence Primer (5'-3') & $\begin{array}{l}\text { TA } \\
\left({ }^{\circ} \mathrm{C}\right)\end{array}$ & Species \\
\hline Bag22 & JQ993454 & (GA)14 & $\begin{array}{l}\text { F:TGTAGTAGTTCTGTCTGCTG } \\
\text { R:TGGAGTTGTTGGTGTGAATC }\end{array}$ & 60 & B. amazonicus \\
\hline Bag27 & JQ993459 & (CA)5GA(CA)4 & $\begin{array}{l}\text { F:CACAGACACAGTCCCTCATT } \\
\text { R:CACACCCCAGAAAGAATGAC }\end{array}$ & 63 & B. amazonicus \\
\hline BoM13 & AF513628 & (CT) 11 & $\begin{array}{c}\text { F: CATTTCCTCAGTCCTTTTCAGC } \\
\text { R: CCCACTTAGGGTCGCAC }\end{array}$ & 47 & B. opalinus \\
\hline Bh6 & DQ408243.1 & (GT)14 & $\begin{array}{l}\text { F: GCGTTGCGTGTGTATGTTAA } \\
\text { R: AGAGGTGTCCACAAAGTTTT }\end{array}$ & 55 & B. hillari \\
\hline Bh5 & DQ408242.1 & $(\mathrm{AC}) 13$ & $\begin{array}{l}\text { F: CTTCCACTCATACCGGCACT } \\
\text { R: ACATCTGGCATTAGGCATAG }\end{array}$ & 55 & B. hillari \\
\hline Borg25 & MF510261.1 & $(\mathrm{GA}) 4$ & $\begin{array}{l}\text { F: AAGGTGCTTTGAGTGATGCC } \\
\text { R: ACCGACCCTTTTGACTCGTA }\end{array}$ & 55 & B. orbignyanus \\
\hline Borg59 & MF510265.1 & $\begin{array}{c}\text { (CT)4CC(CT)5TT } \\
\text { (CT)5(CA)9(CT)3N(CT)7 }\end{array}$ & $\begin{array}{l}\text { F: TCCCTCTCTGTCCAAATGTCT } \\
\text { R: GAAGTCAAGGTTAGAGCGGC }\end{array}$ & 55 & B. orbignyanus \\
\hline
\end{tabular}

\section{Table 2}

Number of alleles (N), size of alleles (bp), content of polymorphic information (PIC), private alleles observed in the breeding stocks (INPA) and (NM) of Brycon amazonicus

\begin{tabular}{|c|c|c|c|c|c|c|c|}
\hline & Bag22 & Bag27 & BoM13 & Bh5 & Bh6 & Borg25 & Borg59 \\
\hline $\mathrm{N}$ & 5 & 5 & 9 & 8 & 5 & 3 & 6 \\
\hline $\mathrm{pb}$ & 318-326 & 297-317 & 187-205 & $221-235$ & $188-205$ & $273-287$ & $212-224$ \\
\hline $\mathrm{PIC}$ & 0.716 & 0.727 & 0.766 & 0.748 & 0.782 & 0.135 & 0.730 \\
\hline \multicolumn{8}{|c|}{ Private alleles (Frequência) } \\
\hline \multirow[t]{6}{*}{ INPA } & $324^{(0.200) ;}$ & $303^{(0.089) ;}$ & $187^{(0.037) ;}$ & $223^{(0.196) ;}$ & & $273^{(0.078)}$ & $212^{(0.030) ;}$ \\
\hline & $326^{(0.020)}$ & $307^{(0.089) ;}$ & $189^{(0.019) ;}$ & $230^{(0.054) i}$ & & & $214^{(0.197) ;}$ \\
\hline & & $315^{(0.036) ;}$ & $191^{(0.204) ;}$ & $233^{(0.321)}$ & & & $224^{(0.167)}$ \\
\hline & & & $193^{(0.185) ;}$ & & & & \\
\hline & & & $201^{(0.037) ;}$ & & & & \\
\hline & & & $205^{(0.019)}$ & & & & \\
\hline \multirow[t]{2}{*}{ NM } & & $317^{(0.050)}$ & & & $221^{(0.059) ;}$ & $283^{(0.015)}$ & \\
\hline & & & & & $224^{(0.721)}$ & & \\
\hline
\end{tabular}


A higher average number of alleles per locus was observed in INPA (5.57) compared to NM (3.57). The lowest indexes of allelic richness (Ra) were observed in NM, with values ranging from 1.588-4.998. The Ra values were higher in INPA with the BoM13 locus presenting the highest value (8.351). The increased Ra in INPA demonstrated that this population had greater adaptation to environmental changes (better segregation of alleles to the next generations) and in the specific case, to the current captivity conditions, provided that adequate reproductive and genetic management was carried out. In contrast, in NM the Ra results revealed that there was a loss of genetic variation, demonstrating that in this stock there was less evolutionary potential; due to the long time in which the individuals had remained in the stock (for more than 10 years). The average observed heterozygosity $(\mathrm{Ho})$ data corroborated this statement and a lower value was observed for NM and INPA (0.475 and 0.545, respectively). However, despite being smaller than the expected heterozygosity $(\mathrm{He})$, the Ho values were high for INPA and NM, demonstrating an adequate genetic variability, with an increase in the number of homozygotes in both populations (Table 3).

\section{Table 3}

Number of alleles by locus ( $\mathrm{Na}$ ), Allelic richness (Ra), Observed (Ho) and expected (He) heterozygosity, Hardy-Weinberg equilibrium test (HWE) and Inbreeding coefficient $\left(F_{I S}\right)$ observed in the breeding stocks (INPA) and (NM) of Brycon amazonicus

\begin{tabular}{cccccccc} 
Population & Locus & Na & Ra & Ho & He & HWE & FIS \\
& Bag22 & 5 & 4.794 & 0.520 & 0.612 & $0.157 n s$ & 0.153 \\
\cline { 2 - 7 } INPA & Bag27 & 6 & 5.634 & 0.571 & 0.698 & $0.157 n s$ & 0.185 \\
& BoM13 & 9 & 8.351 & 0.889 & 0.826 & $0.405 n s$ & -0.078 \\
& Bh5 & 6 & 5.674 & 0.357 & 0.737 & $0.002 n s$ & 0.520 \\
& Bh6 & 5 & 4.999 & 0.843 & 0.786 & $0.099 n s$ & -0.074 \\
& Borg25 & 2 & 1.994 & 0.031 & 0.146 & $0.000 n s$ & 0.789 \\
& Borg59 & 6 & 5.848 & 0.636 & 0.814 & $0.033^{*}$ & 0.221 \\
& Mean & 5.57 & 5.327 & 0.545 & 0.659 & - & 0.245 \\
& Bag22 & 3 & 3.000 & 0.666 & 0.674 & $0.100 \mathrm{~ns}$ & 0.012 \\
& Bag27 & 4 & 4.000 & 0.400 & 0.693 & $0.000 \mathrm{~ns}$ & 0.430 \\
& BoM13 & 3 & 3.000 & 0.606 & 0.631 & $0.018^{*}$ & 0.041 \\
& Bh5 & 5 & 4.151 & 0.382 & 0.446 & $0.000 \mathrm{~ns}$ & 0.146 \\
& Bh6 & 5 & 4.998 & 0.968 & 0.782 & $0.016^{*}$ & -0.243 \\
& Borg25 & 2 & 1.588 & 0.029 & 0.029 & $0.931 \mathrm{~ns}$ & 0.000 \\
& Borg59 & 3 & 3.000 & 0.272 & 0.575 & $0.000 \mathrm{~ns}$ & 0.530 \\
& Mean & 3.57 & 3.391 & 0.475 & 0.547 & - & 0.110
\end{tabular}

ns=not significant, ${ }^{*} \mathrm{P}<0.05$. 
The Ho results were similar to those found in other studies assessing natural populations and breeding stocks of $C$. macropomum. Santos, Santana, Sá Leitão, Paula-Silva and Almeida-Val (2016) have observed mean values of Ho of 0.53 for the natural population and 0.51-0.52 for two breeding stocks, when evaluating a natural population of the Solimões-Amazonas rivers and three breeding stocks. Aguiar et al. (2018) have observed similar values for two breeding stocks (0.41-0.52); however, there are higher values for other stocks and for the natural population from the Amazon River (0.69). The founding effect is an important factor to be considered in genetic diversity analysis of fish farms because the majority of productions have a limited effective population size when the initial stock is created and formed, in addition to the low number of breeders implemented in the production of fingerlings due to the high fertility of the species, which also contributes to the reduction of genetic diversity (Aguiar et al., 2018).

Deviation from the HWE $(P<0.05)$ was observed at the Borg59 locus in INPA and the BoM13 and Bh6 loci in NM. The imbalance for the Borg59 locus in INPA was explained by the effect of null alleles, as evidenced by the Micro-Checker program for that locus. However, it was noteworthy that the average FIS value showed a heterozygote deficit for this population $(0.245)$ that was attributed to anthropic actions that exerted pressure on this population (pollution and overfishing) or the possible presence of a founding effect at the moment of stock formation. For NM, a HWE imbalance was observed in BoM13 and Bh6, a result that was explained by the deficiency and the excess of heterozygotes observed through the FIS (0.041 and -0.243 , respectively).
However, it was noteworthy that when analyzing the average FIS values for this stock, in general, a heterozygote deficit (0.110) was observed that, together with the deviation in the HWE and the difference between Ho and $\mathrm{He}$, demonstrated the presence of genetic drift in this population. The negative FIS values recorded in NM might be related to the reduced effective size of the captive populations and reproductive management in the fish farms (Table 3). In addition to the Borg59 locus, MicroChecker identified null alleles for the Bh5 and Borg25 loci; however, from the observed Ra, $\mathrm{Ho}, \mathrm{He}$, and $\mathrm{HWE}$ results, the influence of these alleles on the frequencies and intra-population results obtained were not verified.

The AMOVA showed that most of the variation was within (91.36) and not between populations (8.64). This result is corroborated by the FST index (0.086), which, according to Wright's classification demonstrates a moderate genetic differentiation between INPA and NM (Table 4). The DG and IG values (0.273 and 0.761, respectively) confirmed this differentiation. These results revealed that NM might have come from INPA; however, they differed genetically. This divergence was identified in the Bayesian analysis, which designated a value of $K=2$, with the presence of structuring for NM and INPA. However, this was correlated allelic frequencies, confirming a common origin (Figure 1). This origin was also supported by the presence of gene flow through the number of migrants $(5,691)$. The productive management adopted over the years in NM (mating and the introduction of new breeders) may have contributed to this genetic differentiation; however, it was insufficient for the isolation to totally reduce the frequencies shared with INPA. 


\section{Table 4}

Number of alleles by locus ( $\mathrm{Na}$ ), Allelic richness (Ra), Observed (Ho) and expected (He) heterozygosity, Hardy-Weinberg equilibrium test (HWE) and Inbreeding coefficient $\left(F_{15}\right)$ observed in the breeding stocks (INPA) and (NM) of Brycon amazonicus

\begin{tabular}{cccccc} 
Variation Source & $\begin{array}{c}\text { Sum of } \\
\text { squares }\end{array}$ & $\begin{array}{c}\text { Variance } \\
\text { Components }\end{array}$ & $\begin{array}{c}\text { Percentage of } \\
\text { variation }\end{array}$ & FST & Wr \\
\hline Between the populations & 5.408 & 0.06974 & $8.64^{*}$ & 0.086 & Moderate \\
Within the populations & 97.308 & 0.73718 & 91.36 & &
\end{tabular}

${ }^{*} \mathrm{P}<0.05$.

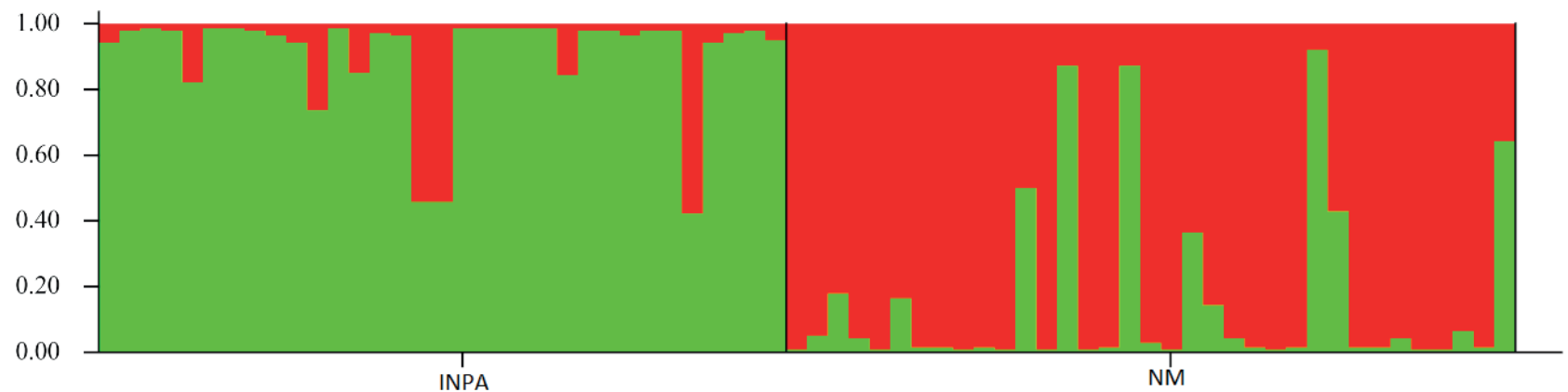

Figure 1. Bayesian cluster analysis $(K=2)$ from the Brycon amazonicus breeding stocks, run in the Structure program. (INPA) INPA and (NM) Nova Mutum.

Based on these results, it is recommended that new individuals be incorporated (based on genetic analysis) in NM, because, despite the maintenance of adequate genetic variability, there is a deficit of heterozygotes due to genetic drift. Because of their common ancestry, these new individuals may come from INPA, thus avoiding genetic introgression in the stock. The importance of periodically evaluating stock genetic diversity is also stressed, to direct reproductive management by integrating a larger number of individuals that avoid decreasing genetic variability (Povh et al., 2008).

Regarding INPA, managements that allow all animals to have the opportunity to reproduce (breeder breeding) and inbreeding control must be adopted. Other measures, such as equalizing the size of families, maximizing the duration of generations (Frankham, Ballou, \& Briscoe, 2008), using the best reproductive system to avoid mortality, and allowing better participation of breeders (Souza et al., 2018b) may also be adopted to prevent inbreeding depression. One-off replenishment of the squad with wild individuals from the same collection site as the original individuals (Oliveira et al., 2018) may be a future measure for genetic control of this stock.

The conservation of the genetic variability of fish populations is essential to maintain their ability to adapt and respond to environmental changes (Povh et al., 2008; Ribeiro et al., 2016), and is a priority in captive stocks kept for the purpose of developing strategies that reduce genetic erosion and 
minimize risks of inbreeding depression (Aguiar et al., 2018; Lopera-Barrero et al., 2015). In addition, aquaculture is important as an alternative to minimize the problem of overfishing, as the creation of exhaustively caught species, such as B. amazonicus, may reduce the demand of wild individuals and relieve pressure on natural populations (Oliveira et al., 2018).

\section{Conclusions}

Moderate genetic variability and a common genetic origin were observed in the INPA and NM breeding stocks.

\section{Acknowledgments}

The authors would like to thank the "Conselho Nacional de Desenvolvimento Científico e Tecnológico (CNPq)", the "Coordenação de Aperfeiçoamento de Pessoal de Nível Superior" (CAPES), and the "Programa de Pós Graduação em Ciência Animal (Universidade Estadual de Londrina)" for scholarships and financial support.

\section{References}

Abreu, J. S., \& Urbinati, E. C. (2006). Physiological responses of matrinxã (Brycon amazonicus) fed different levels of vitamin c and submitted to air exposure. Acta Amazônica, 36(4), 519-524. doi: 10. 1590/S0044-59672006000400013

Aguiar, J. P., Gomes, P. F. F., Hamoy, I. G., Santos, S. E. B., Schneider, H., \& Sampaio, I. (2018). Loss of genetic variability in the captive stocks of tambaqui, Colossoma macropomum (Cuvier, 1818), at breeding centers in Brazil, and their divergence from wild populations. Aquaculture Research, 49(5), 1914-1925. doi: 10.1111/are.13647

Araujo, G. T. C. D. (2012). Isolamento, caracterização de locus microssatélites e estimativa da variabilidade genética de Brycon amazonicus (Spix \& Agassiz, 1829) (Characidae: Bryconinae) em ambiente natural e cativeiro. Dissertação de mestrado, Instituto Nacional de Pesquisas da Amazônia, Manaus, AM, Brasil.

Araujo-Dairiki, T. B., Chaves, F. C. M., \& Dairiki, J. K. (2018). Sementes de sacha inchi (Plukenetia volubilis, Euphorbiaceae) em rações para juvenis de tambaqui, Colossoma macropomum, e matrinxã, Brycon amazonicus (Characidae). Acta Amazônica, 48(1), 32-37. doi: 10.1590/1809-4392201700753

Barroso, R. M., Hilsdorf, A. W. S., Moreira, H. L. M., Mello, A. M., Guimarães, S.E. F., Cabello, P.H., \& Traub-Cseko, Y. M. (2003). Identification and characterization of microsatellites loci in Brycon opalinus (Cuvier, 1819) (Characiformes, Characidae, Bryconinae). Molecular Ecology Notes, 3(2), 297-298. doi: 10.1046/j.1471-8286.2003.00435.x

Botstein, D., White, R. L., Skolnick, M., \& Davis, R. W. (1980). Construction of a genetic linkage map in man using restriction fragment length polymorphisms. American Journal of Human Genetics, 32(3), 314-331.

Castro, P. L. D., Ribeiro, R. P., Santos, S. C. A. D., Goes, E. S. D. R., Souza, F. P. D., Poveda-Parra, A. R.,... Lopera-Barrero, N. M. (2017). Cross-amplification of heterologous microsatellite markers in Piracanjuba. Ciência Rural, 47(12), 1-6. doi: 10.1590/0103-8478cr20170374 
Earl, D. A. (2012). STRUCTURE HARVESTER: a website and program for visualizing STRUCTURE output and implementing the Evanno method. Conservation Genetics Resources, 4(2), 359-361. doi: 10. 1007/ s12686-011-9548-7

Evanno, G., Regnaut, S., \& Goudet, J. (2005). Detecting the number of clusters of individuals using the software STRUCTURE: a simulation study. Molecular Ecology, 14(8), 2611-2620. doi: 10.1111/j. 1365-294X.2005.02553.x

Excoffier, L., \& Lischer, H. E. (2010). Arlequin suite ver 3.5: a new series of programs to perform population genetics analyses under Linux and Windows. Molecular Ecology Resources, 10(3), 564-567. doi: 10.1111/j.1755-0998.2010.02847.x

Frankham, R., Ballou, J. D., \& Briscoe, D. A. (2008). Fundamentos de genética da conservação. Ribeirão Preto: Sociedade Brasileira de Genética.

Goudet, J. (2005). FSTAT: a program to estimate and test gene diversities and fixation indices (version 2.9.3.2). Lausanne: University of Lausanne, Department of Ecology \& Evolution.

Instituto Brasileiro de Geografia e Estatística (2016). Produção da Pecuária Municipal. São Paulo, IBGE.

Kalinowski, S. T., Taper, M. L., \& Marshall, T. C. (2007). Revising how the computer program CERVUS accommodates genotyping error increases success in paternity assignment. Molecular Ecology, 16(5), 1099-1106. doi: 10.1111/j.1365-294X.2007.03089.x

Lima, F. C. T. (2003). Subfamily Bryconinae (Characins, Tetras). In R. E. Reis, S. O. Kullander, \& C. J. Ferraris (Eds.), RE check list of the freshwater fishes of South and Central America. Porto Alegre, RS: EDPURCS.

Lopera-Barrero, N.M.,Alvarez,C.A.R., RodriguezRodriguez, M. D. P., Povh, J. A., Vargas, L., Streit, D. P., Jr.,... Ribeiro, R. P. (2014). Diversidade genética e paternidade de progênies de Brycon orbignyanus obtidas por diferentes sistemas reprodutivos. Semina: Ciências Agrárias, 35(1), 541-554. doi: 10.5433/ 1679-0359.2014v35n1p541

Lopera-Barrero, N. M., Povh, J. A., Ribeiro, R. P., Gomes, P. C., Jacometo, C. B., \& Silva Lopes, T. D. (2008). Comparación de protocolos de extracción de ADN con muestras de aleta y larva de peces: extracción modificada con cloruro de sodio. Ciencia e Investigación Agraria, 35(1), 77-86. doi: 10. 4067/S0718-16202008000100008

Lopera-Barrero, N. M., Rodriguez-Rodriguez, M. D. P., Fornari, D. C., Resende, E. K., PovedaParra, A. R., Braccini, G.,... Ribeiro, R. P. (2015). Genetic variability of broodstocks of Tambaqui (Teleostei-Characidae) from the northeast region of Brazil. Semina: Ciências Agrárias, 36(6), 4013-4021. doi: 10. 5433/1679-0359.2015v36n6p4013

Oliveira, R. C., Santos, M. D. C. F., Bernardino, G., Hrbek, T., \& Farias, I. P. (2018). From river to farm: an evaluation of genetic diversity in wild and aquaculture stocks of Brycon amazonicus (Spix \& Agassiz, 1829), Characidae, Bryconinae. Hydrobiologia, 805(1), 75-88. doi: 10.1007/s10750-0173278-0

Peakall, R., \& Smouse, P. E. (2012). GenAlEx 6.5: genetic analysis in Excel. Population genetic software for teaching and research - an update. Bioinformatics, 28(19), 25372539. doi: 10.1093/bioinformatics/bts 460 
Povh, J. A., Lopera-Barrero, N. M., Ribeiro, R. P., Lupchinski, E., Gomes, P. C., \& Lopes, T. S. (2008). Monitoreo genético en programas de repoblamiento de peces mediante marcadores moleculares. Ciencia e Investigación Agraria, 35(1), 5-15. doi: 10.4067/S0718-16202008000100001

Pritchard, J. K., Stephens, M., \& Donnelly, P. (2000). Inference of population structure using multilocus genotype data. Genetics, 155(2), 945-959.

Ribeiro, R. P., Rodriguez-Rodriguez, M. D. P., Resende, E. K., Souza, F. P., Povh, J. A., Poveda-Parra, A. R.,... Lopera-Barrero, N. M. (2016).Genetic characteristicsofTambaqui broodstocks in the state of Rondônia, Brazil: implications on production and conservation. Semina: Ciências Agrárias, 37(4), 2375-2385. doi: 10.5433/1679-03 59.2016v37n4Supl1p2375

Rice, W. R. (1989). Analyzing tables of statistical tests. Evolution, 43(1), 223-225. doi: $10.2307 / 2409177$

Sanches, A., \& Galetti, P. M. (2006). Microsatellites loci isolated in the freshwater fish Brycon hilarii. Molecular Ecology Notes, 6(4), 1045-1046. doi: 10.1111/j.1471-8286.2006.01427.x

Santos, C. H. A., Santana, G. X., Sá Leitão, C. S., Paula-Silva, M. N., \& Almeida-Val, V. M. F. (2016). Loss of genetic diversity in farmed populations of Colossoma macropomum estimated by microsatellites. Animal Genetics, 47(3), 373-376. doi: 10.1111/ age. 12422

Santos, L. C., \& Batista, V. S. (2009). Dinâmica populacional da matrinxã Brycon amazonicus (Characidae) na Amazônia central. Zoologia, 26(2),195-203. doi: 10.1590/S1984-46702009000200001
Silva, R. C., Santos, P. M. D., Senhorini, J. A., Paes, M. D. C. F., Valentin, F. N., Fujimoto, T.,... Nakaghi, L. S. O. (2017). The effect of temperature on the initial development of Brycon amazonicus Spix \& Agassiz, 1829 as tools for micromanipulation of embryos. Zygote, 25(5), 637-651. doi: 10.1017/S09671 9941700051X.

Souza, F. P. D., Lima, E. C. S. D., Castro, P. L. D., Goes, E. D. S. D. R., Ribeiro, R. P., \& Lopera-Barrero, N. M. (2018b). Parental contribution of Curimba offspring in different reproductive systems. Boletim do Instituto de Pesca, 44(1), 74-79. doi: 10.20950/1678-2305.2018.276

Souza, F. P. D., Urrea-Rojas, A. M., Ruas, C. D. F., Povh, J.A., Ribeiro, R.P., Ruas, E. A.,...LoperaBarrero, N. M. (2018a). Novel microsatellite markers for the endangered neotropical fish Brycon orbignyanus and crossamplification in related species. Italian Journal of Animal Science, 17(4), 916-920. doi: 10.1080/1828051X.2018.1436008

Van Oosterhout, C., Hutchinson, W. F., Wills, D. P. M., \& Shipley, P. (2004). MICROCHECKER: software for identifying and correcting genotyping errors in microsatellite data. Molecular Ecology Notes, 4(3), 535-538. doi: 10.1111/j.1471-8286.2004.00684.x

Wright, S. (1978). Evolution and genetics of populations: a treatise in four volumes: Vol. 4: variability within and among natural populations (4nd ed.). Chicago: University of Chicago.

Yeh, F. C., Boyle, T. Y. Z., \& Xiyan, J. M. (1999). PopGene Version 1.31: Microsoft Window based freeware for population genetic analysis: quick user guide. 